\section{FORMATION AND BREAKDOWN OF SERPULID TUBES}

\author{
BY JEAN HANSON \\ Bedford College, University of London
}

$\mathrm{D}^{2}$

URING an investigation of the blood systems of serpulid worms (Annelida, Polychæta), opportunities occurred to make the following observations on the mode of formation and breakdown of the calcareous tubes in which these animals live.

Although much research has been carried out on the asexual reproduction of Salmacina and Filograna by Malaquin, Faulkner ${ }^{1}$ and others, it is not known how a newly formed individual leaves its parent's tube and makes its own tube. During last summer, specimens of Salmacina incrustans Claparede settled on the sides of a glass aquarium in the Zoological Station at Naples, and daily observations were made on the growth of the colonies. The new individual is formed at the posterior end of the parent, and after separation it moves backwards down the parent's tube and makes a hole in the side of the tube from which it protrudes its branchial crown (Fig. 1, X). It may destroy the posterior end of the parent's tube and thus separate it from the rest of the colony $(Y)$. It may also form a new tube which grows out from the original opening $(Z)$. These colonies spread out over the wall of the aquarium. Colonies taken from the sea usually consist of masses of entangled tubes raised off the substratum to which the basal parts are attached. These three-dimensional colonies are built up of tubes with side-branches which are presumably formed in the same way as in the twodimensional colonies growing in the aquarium.

It is not known how the newly separated bud makes the hole in the side of its parent's tube. One is reminded of the ability of the sabellid Potamilla to bore into calcareous rocks ${ }^{2}$. At Naples Potamilla often lives inside the walls of the calcareous shell of the molluse Vermetus. How Potamilla bores its holes is also unknown. Some observations of $\mathrm{Fox}^{3,4}$ are interesting in this connexion. $\mathrm{He}_{\mathrm{e}}$ has found that when the anterior end of the tube of Sabella spallanzanii is artificially closed, the animal can make a hole in the side of the tube, from which it then protrudes its branchial crown. The tube of Sabella consists largely of mucus and is not calcareous.

Alkaline phosphatase is probably concerned in the calcification of bone and in the formation of the calcareous shells of molluscs ${ }^{5}$. It was therefore interesting to find this enzyme in Pomatoceros triqueter L. (Fig. 2) which; like the other serpulids,
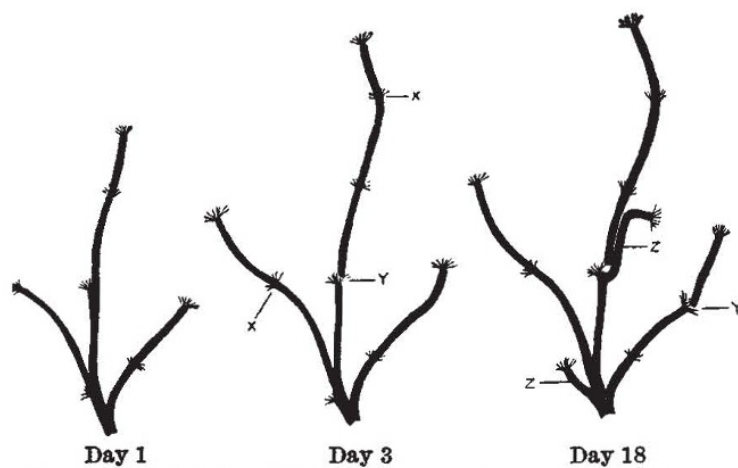

Fig. 1. FRERHAND DRAWING OF ONE PART OF DAy 18 COLONY OY Salmacina incrustans ON FIRST, THIRD AND EIGHTHENTH DAYS OF OBSERVATION

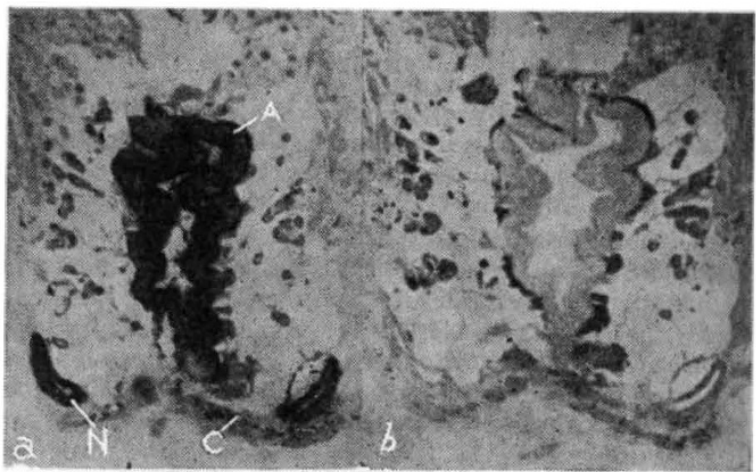

Fig. 2. PHOTOMICROGRAPHS OF HORIZONTAL LONGITUDINAI SECTIONS THROUGH THE THORAX OF Pomatoceros triqueter. $\times 25$ (SITES OF FNZYME BLACK); (b) CONTROI

builds a calcareous tube. When Pomatoceros is removed from its tube, it begins to form a new one ${ }^{6}$. The new tube first appears on the ventral surface of the anterior part of the thorax under the ventral collar fold. It is not known how this new tube is produced; but it seems likely that it is secreted by glands in this part of the thorax.

One specimen of Pomatoceros, fixed immediately after removal from its tube, was sectioned and tested for alkaline phosphatase by Gomori's method?. The enzyme was found in the following places:

(1) The epithelium of the alimentary canal (Fig. 2, $A$ ) from the posterior end of the cesophagus to within a few segments of the anus. This is the part of the alimentary canal concerned with the digestion and absorption of food ${ }^{8}$. Phosphatase was concentrated at the inner and outer borders of the cells and was also found in the nuclei and in small granules in the rest of the cytoplasm. There was a thick deposit of phosphatase on the cilia. Bourne ${ }^{5}$ has shown that the enzyme is confined to the absorptive regions of the guinea pig's alimentary canal and is there concentrated in the brush borders of the epithelium. $\mathrm{He}_{e}$ has discussed the hypothesis that alkaline phosphatase is concerned in the phosphorylation of sugars being absorbed from the canal.

(2) The epithelia of the thoracic nephridia (Fig. $2, N)$ and their ducts. In the excretory sacs of the nephridia the phosphatase was distributed in the same fashion as in the gut epithelium, and was also present on the cilia. Alkaline phosphatase has been seen in the brush borders of the proximal convoluted tubules of the mammalian kidney ${ }^{7}$ and in the brush borders of the Malpighian tubules of the goat-moth caterpillar and a spider ${ }^{9}$. Danielli ${ }^{7}$ has discussed the suggestion that in the kidney alkaline phosphatase plays a part in the reabsorption of substances from the glomerular filtrate.

(3) The contents of the alimentary canal.

(4) The chloragosomes (yellow- or brown-coloured globules) in the chlorogogen cells which in serpulids lie on the thoracic ring vessels. Globules of similar appearance, also giving a positive phosphatase reaction, are found in the epithelium of the excretory sacs of the thoracic nephridia. According to Lieb. mann $^{10}$ chloragosomes contain food substances, and he has found that in the chloragosomes of the oligochæte Eisenia foetida, phospholipins are transformed into fats, lipoproteins appearing as transitional substances. Alkaline phosphatase may play some part in this process. 
A second specimen of Pomatoceros was fixed three days after it had been removed from its tube; it had not begun to form a new tube. Alkaline phosphatase was again found in the same four sites as in the other specimen, and also in the following places (Fig. 2):

(5) The borders of small irregular cavities $(C)$ situated in the thick epithelium on the ventral sur. face of the thorax under the ventral collar fold. This is the tissue which probably secretes the calcareous tube, and alkaline phosphatase is perhaps concerned in this process, as it seems to be in the calcification of bone and in the formation of the calcareous shells of molluscs ${ }^{5}$.

(6) The epithelium of the dorsal and ventral lips of the mouth.

(7) The nuclei of the endothelium in the walls of the blood vessels in some of the pinnules of the branchial crown. Bourne ${ }^{5}$ has found the enzyme in endothelial nuclei of vertebrate capillaries.

I wish to thank the staff of the Zoological Station of Naples, the British Association for the Advance. ment of Science for the use of its Table, and the University of London for a grant towards travelling expenses. I am also indebted to Dr. A. Stock for advice on the use of Gomori's method.

${ }^{1}$ Faulkner, G. H., J. Linn. Soc. (Zool.), 37, 109 (1930). This includes references to Malaquin's work.

${ }^{2}$ McIntosh, W. C., "British Marine Annelids", 4 (Ray Society, London, 1922-23).

${ }^{3}$ Fox, H. Munro, Proc. Roy. Soc., B, 112, 479 (1933).

- Fox, H. Munro, Proc. Roy. Soc., B, 125, 554 (1938).

- Bourne, G., Quart. J. Exp. Physiol., 32, 1 (1944).

- Faouzi, H., J. Mar. Biol. Assoc. U.K., 17, 379 (1930-31).

" Danielli, J. F., J. Exp. Biol., 22, 110 (1946).

${ }^{8}$ Thomas, J. G., "Pomatoceros, Sabella and Amphitrite" (Liverpool, 1940 ).

- Bradfield, J. R. G., Nature, 157, 876 (1946).

${ }^{10}$ Liebmann, E., J. Morph., 70, 151 (1942).

\section{PLANT VIRUS PROTEINS AND ANTIBODY-ANTIGEN REACTIONS}

\section{By R. E. F. MATTHEWS}

Plant Virus Research Unit, Molteno Institute, Cambridge

$\mathrm{P}$

ROTEIN mixtures such as those found in blood have been widely used in the study of antibodyantigen reactions. It is difficult to prepare pure samples of single proteins from such naturally occurring mixtures. On the other hand, preparations of certain plant virus proteins, derived from a single infectious unit, can be isolated in quantities sufficient for experimental work in a state which fulfils all the usual criteria of homogeneity. As they are also good antigens, they would appear to be especially suitable objects for the study of antibody-antigen reactions.

The method used by Boyd ${ }^{1}$ has been applied to the study of the turnip yellow mosaic virus antisera produced in rabbits. Successive doses of $0.01,0 \cdot 1$, $1 \cdot 0,10 \cdot 0$, and $100 \cdot 0 \mathrm{mgm}$. of turnip yellow mosaic virus $^{2}$ (prepared by the method of Markham and Smith $^{3}$ ) were given intravenously to a single rabbit. Bleedings were taken two weeks after each injection, followed by a rest period of a few days before the next injection.

The antiserum produced by the $0.01 \mathrm{mgm}$. injec. tion was of low titre with marked suppression of precipitation in the region of antiserum excess. This antiserum would be of the $H$ type according to Boyd's classification. With increasing dosage of antigen the antiserum produced gave progressively higher titres,

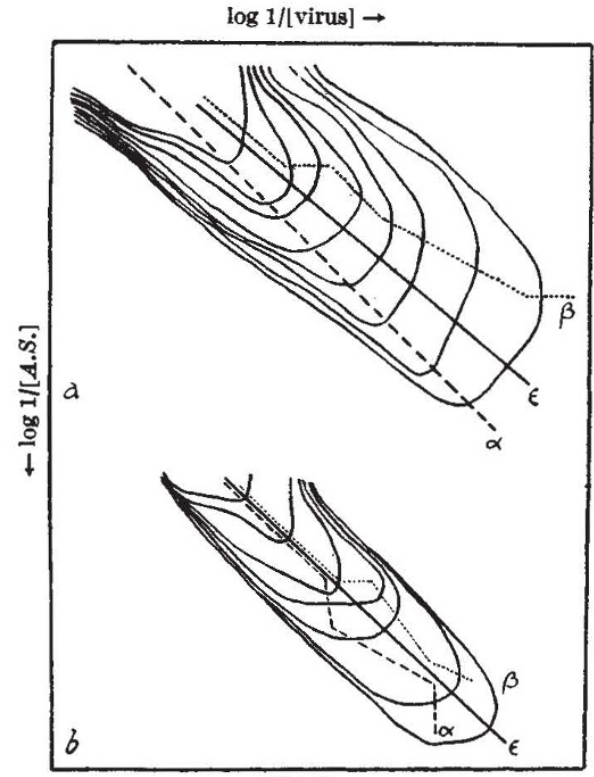

Fig. 1

and the type of precipitating system produced tended progressively towards Boyd's $R$ type, with lessmarked inhibition in the region of antiserum excess.

Fig. la shows the precipitating system for the antiserum produced after the $0.01 \mathrm{mgm}$. plus 0.1 mgm. injections. Fig. 2 shows the system for the antiserum from the same rabbit after the full course of injections.

If this antiserum obtained after the full course of injections is diluted with normal serum to make its titre approximate to one of the earlier antisera obtained, then the type of system produced approximates fairly closely to that produced by the earlier bleeding. For example, the antiserum obtained after the full course of injections (with a titre of $1: 8192$ ) was diluted to $1: 256$ with normal serum and a precipitation diagram prepared (Fig. 1b). This antiserum precipitated to a titre of $1: 64$, and there was fairly marked inhibition in the region of antiserum excess similar in amount to that found for the antiserum of Fig. $1 a$ with a titre of $1: 128$.

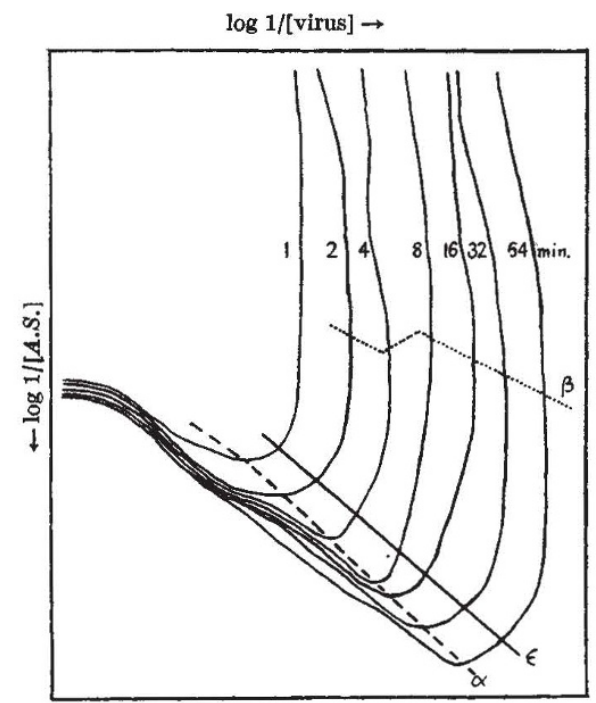

Fig. 2 